Anna Sereda

Kharkiv National University of Radio Electronics,

Senior Lector

\title{
COGNITIVE-DISCOURSE APPROACH AS A METHODOLOGY FOR THE ANALYSIS OF INTERCULTURAL COMMUNICATION
}

The given work is devoted to the methodology of analysis of intercultural communication. The cognitive-discursive approach is the way to methodologically correct understanding and interpretation of language categories and development of optimal form of voice messages in order to achieve a successful communication. Cognitive-discursive approach allows us to consider discourse as an integrative phenomenon, thought-communicative activity, which takes place in a broad sociocultural context.

Key words: communication, discourse, cognitive-communicative paradigm, socio-cultural conditionality of discourse. \section{Г.Ю. Середа МІжКУЛЬТУРНОї КОМУНІКАЦІї}

Дана робота присвячена методології аналізу міжкультурної комунікації. Когнітивнодискурсивний підхід є шляхом до методологічно коректного розуміння і тлумачення мовних категорій $i$ вироблення оптимальної форми мовних повідомлень з метою досягнення успішності комунікаиії. Когнітивно-дискурсивний підхід дозволяе розглядати дискурс як інтегративний феномен, мисленнєво-комунікативну діяльність, яка протікає в широкому соціокультурному контексті.

Ключові слова: комунікачія, дискурс, когнітивно-комунікативна парадигма, соціальнокультурна обумовленість дискурсу.

(C) Sereda A., 2018 


\title{
КОГНИТИВНО-ДИСКУРСИВНЫЙ ПОДХОД КАК МЕТОДОЛОГИЯ АНА. Середа МЕЖКУЛЬТУРНОЙ КОММУНИКАЦИИ
}

\begin{abstract}
Данная работа посвящена методологии анализа межкультурной коммуникаиии. Когнитивно-дискурсивный подход является путем к методологически корректному пониманию и толкованию языковых категорий и выработке оптимальной формы речевых сообщений с цุелью достижения успешности коммуникации. Когнитивно-дискурсивный подход позволяет рассматривать дискурс как интегративный феномен, мыслительно-коммуникативную деятельность, которая протекает в широком соииокультурном контексте.
\end{abstract}

Ключевые слова: коммуникация, дискурс, когнитивно-коммуникативная парадигма, сочиально-культурная обусловленность дискурса.

Now, globalization has covered all spheres of human life and made the problem of success of communication, especially cross-cultural communication, urgent. The modern development of computer technology allows you to exchange messages within a few seconds, even if people are at different ends of the Earth. The problem of success of communication is interdisciplinary. Various aspects of this problem are considered by such sciences as cognitive linguistics, psychology, philosophy, logic, culturology, ethnography, aesthetics, semiotics, hermeneutics, etc. In the modern philosophy of language, a lot of attention is paid to the cognitive aspects of communicative interactions.

The beginning of XXI century was marked in science by the formation of a new cognitive-communicative paradigm of scientific research. Within the frameworks of new scientific paradigm, linguistic-cognitive approach to discourse analysis has developed, which greatly expands methodological and methodical potential of analysis of communication in general and intercultural communication particularly.

The actuality of research is conditioned by requirements of the time: globalization and informatization of all spheres of human life, modern state of humanities, development of nonlinear scientific paradigm and consists in the need to comprehend communication in the light of the new linguistic cognitive paradigm.

The aspiration of the research is to try to understand what and how is stored in the mind of a person, how the individual operates these "storage units», how they manifest themselves in the language, how they affect the communication process. This is an attempt to reveal how we look at the world and evaluate it, how our consciousness functions, how the picture of the human world and its activities are reflected in its speech and influence communicative behavior, causing its success or provoking communicative failures.

Within the frameworks of cognitive-communicative paradigm, person is considered as having a special cognitive system that represents interrelated thinking, consciousness and speech and carries out the processing and storage of information. Information processing is carried out in acts of thought. Primary information about some events in the external world comes to the senses of the person, processed by thinking and transferred to memory in the form of mental interpretation, on the basis of which the mind develops a conviction about the external world. Consciousness operates not only with knowledge, but also with thoughts, assessments, beliefs. It forms more or less complete picture of the world, which predetermines human behavior.

The word «cognitive» in the meaning «cognitive» has been encountered in philosophical literature for a long time. But with the development of cognitive psychology, which studies mental processes, the term «cognitive» has greatly enriched, has become broader. Ray Jackendoff defines cognitive theory as the study of mental information, that is, information stored in the mental vocabulary within the brain and making up the base of human consciousness [1]. 
Cognitologists pay attention to the difference between scientific knowledge of the world and constant flow of cognition, which is aimed at simple interaction with the world in the sphere of our daily and everyday experience. Scientific knowledge is oriented toward obtaining truth, and cognition is for purely pragmatic purposes. Language reflects the results of cognition as a process aimed at solving practical problems of human adaptation to the environment, classification of direct perception data, dismemberment of the flow of information, and so on. But for studying cognitive aspects of communication there is not enough knowledge about the language, it is necessary to take into account such factors as the time and place of communicative act, the age and social status of its participants, intentions, motives, peculiarities of mental processes of communicants.

Cognitive activity of the person occurs through the classification, categorization and conceptualization of reality. The integrative basis of cognitive science is the principle of categorization of the world, the picture of which consists of the unity of gnoseological and linguistic principles: on the one hand, there is a system of images (the ontological picture of the world) in the mind of man, and on the other - this system is actualized with the help of natural language (the language picture of the world ). Language is a system of verbalized knowledge of the world and is a material construct through which a conceptual picture of the world is constituted - a phenomenon that is reflected in the consciousness of a person in the form of a secondary existence of the objective world and which is the result of abstraction.

The language picture of the world arises in the ordinary consciousness of a certain linguocultural community in the form of individual and collective experience and it is a linguistic reflection of the totality of knowledge and ideas about the world peculiar to this community. Language and conceptual pictures of the world are inextricably linked by a verbal factor. However, they differ: first is based on the categorization of reality, and second on its conceptualization. The language picture of the world operates with linguistic signs, and conceptual picture of the world - images and concepts. Together they are able to unite in a frame. A frame is a cognitive model, in which representations, images, concepts, concepts stored in memory are organized. Frame concepts allow you to model understanding.

The cognitive approach makes it possible to consider units of language as a source of data on conceptual or cognitive structures of consciousness. Units of language are transformed into units of speech in the course of a person's discursive (communicative) activity. Studying this or that language, it is necessary to take into account the inseparable connection of its two main functions - cognitive and communicative. Mastering someone else's language involves not just learning its vocabulary and grammar rules, but also deepening into the ethno-cultural and social context in which this language functions, into a picture of the world behind words in that language.

Communication is the transfer of information from person to person, a specific form of interaction between people in processes of their cognitive and labor activity, carried out with the help of language or writing. Communication is carried out in the form of single communicative acts that take place in the context of a certain communicative and pragmatic space, or context. Participants in the communicative act (communicants) generate statements and interpret them. The nature and success of communication are influenced by many factors, particularly, relationships of communicants, their practical goals and communicative intentions, social statuses, code that used and the degree of knowledge of this code by communication participants, preliminary knowledge of objects addressed by addressee (the recipient of the message) his ability to understand the utterance of sender (sender of the message). Each of participants in the discourse has its own set of these factors. At the same time, their meaningful filling of communicants almost never coincides, which is especially noticeable in the case of intercultural discourse.

Human communication is subject to conventions adopted in a given ethnic culture or in a given social group. Speech intentions only then are successfully realized when 
implemented with the help of language tools that are optimal for meeting mutual expectations of communicants. Intentions of the speaker are best conveyed in a conventional way. Intent and convention complement each other. With intercultural communication, communicants' intentions are more difficult to convey, because each of them is subject to conventions of his culture. It is even more difficult to realize intentions, if the language of communication is not native to any of the communicants.

The communicative situation is realized in the speech activity of a person in the form of a speech act. Communicative act is a broader concept than speech, because it can have a non-verbal embodiment. A group of communicative acts united by a common intentional setting into one speech block for the realization of a specific goal is a discursive act.

Communicative-philosophical approach to discourse considers it as a kind of social practice, as a form of social interaction, which is determined by values, social norms and conventions. J. Habermas interprets discourse as «communicative culture of society» [2].

Discourse is an integrative phenomenon, a thought-communicative activity that takes place in a broad socio-cultural context and has both linguistic and extralinguistic plans. It is a combination of process and result and is characterized by continuity and dialogicality. The understanding of discourse as an integrative phenomenon is based on an activity approach to the study of communication. The basis of such an understanding of discourse is the general scientific theory of synergism and nonlinearity.

Teun A. van Dijk believes that «... discourse is not simply an isolated textual or dialogical structure. Rather it is a complex communicative event that also embodies a social context, featuring participants (and their properties) as well as production and reception processes» [3].

A great contribution to the development of the theory of discourse was made by M. L. Makarov, who points out that fundamentally new ontology of socio-psychological, human humanitarian world has replaced the traditional ontology of the material physical world. The introduction of the notion of discourse as a succession of acts of communication as an object of research has allowed to go beyond the limits of the mechanistic paradigm, because discourse can not uniquely determine the type and properties of the following act, it only sets conditions under which the next speech act will be more or less expected. A new nonlinear ontology does not allow unambiguous determinism and is characterized by probabilistic dependences [4]. This is a nonlinear activity ontology, which corresponds to the postmodernism in science.

The cognitive aspect of discourse is that mental discourse is based on mental structures (concepts, cognitive schemes). Mental space is a dynamic form of mental experience, which is actualized in conditions of cognitive interaction of subject with the world. The result of functioning of mental space is the context. The actual mental image of this or that communicative event is its mental representation. Thus, in discourse, the world is reflected only as a representation, that is, as a reflection of the mental reality that has formed outside of it. Objects of knowledge are constructed in discourse, and not passively reflected in it. The study of these processes is impossible without the mutual integration of cognitive and communicative paradigms.

The cognitive-discursive approach can serve as a key to a methodologically correct understanding and interpretation of language categories and development of an optimal form for the proper formulation of voice messages in order to achieve a successful communication. Communication can be successful if communicants build spaces of a similar configuration based on the same linguistic and pragmatic data. That is, communication is the result of the process of construction [5].

The basis of cognitive-communicative paradigm is the recognition of anthropocentricity, the activity and systemic nature of language and speech. In the cognitivecommunicative paradigm, constructivism is the main principle: meaning is not contained in 
discourse, but is constructed by communicants in the course of social interaction taking into account the sociocultural properties of the communication situation and cognitive aspects of communicants. Introduced in linguistics, the principle of constructivism allows us to see how the meanings of individual linguistic utterances are jointly formed by two communicants. In the process of communication, the meaning-constructs arise as a result of a sequence of mutual changes in the competences of communicants.

Thus, communication is a constructive factor of people's behavior and activity, and not just the exchange of information. This emphasizes the equal importance of the addressee and the recipient for communication, their active role in the joint construction of meanings in the process of discursive exchange. It is no accident that social sciences are now turning to the analysis of discourse as a methodology. Understanding of discourse it is possible only against the background of a broad social context.

In the process of creating a discourse, communicants constantly change the model of the current discourse space. The ability of a discourse to be interpreted is determined not only by the accuracy and clarity of the expression, but also by mental characteristics of communicants (pictures of the world, ways of conceptualizing and categorizing reality, etc.), their pragmatic attitudes. Communicative strategies are cognitive processes to which the speaker relates his communicative goals to their linguistic expression. Important for understanding the discourse as a process is also change of roles (turn-taking), because the communicative initiative directly regulates the course of steps in the dialogic discourse.

Knowledge, which is contained in the consciousness of individual and actualized in his discursive activity, is heterogeneous. These are socially shared knowledge, cultural knowledge and idiosyncratic knowledge. This knowledge forms the basis of human communicative behavior.

The aggregate of knowledge shared by members of socio-cultural community is organized in the form of cultural cognitive models that are held in the minds of members of this community and which can co-exist with other, personal (idiosyncratic) models of experience [6]. These models serve both for determination actions of individual himself, and for interpretation actions of others.

Cultural cognitive models are represented in the mind of a person in the form of knowledge structures (frames) that systematically organize his social and individual experience, determine his picture of the world, make up the motivational basis of individual behavior.

G. Lakoff offers to divide the models of knowledge into prepositional and imageschematic. Similarly, cultural cognitive models of representation of knowledge also come in two forms: propositional-schema and image-schema [7].

Propositional schemes are part of socially shared knowledge and cultural knowledge and are understood by all members of cultural community. They provide rapid inference in familiar situations. Imagery schemes are represented as gestalts.

The socio-cultural conditioning of discourse is especially important in intercultural communication. Intercultural discursive interaction is a process of communication between communicants who are carriers of various cultural cognitive models, represent different sociocultural communities. In addition, carriers of different languages may have different discursive strategies and different value orientations. When interlingual intercultural communication, individual elements of discourse in one language turn out to be specific from the point of view of discourse in another language, it can create difficulties in translating in both directions.

In the context of intercultural communication, analysis of discursive activity of people reveals features of thinking and verbal behavior of carriers of various linguistic cultures. Discourse, which is viewed from the point of view of bearer of another language and another culture, is characterized by a large number of specific elements having a different nature. 
Intercultural discourse is characterized by a high degree of divergence in the content of the main communicative factors among the participants in communication. Sometimes this can cause communication failures.

Conclusions. The formation of a new cognitive-communicative paradigm proceeds from a philosophical treatment of cognition based on human experience and a system-activity understanding of verbal interaction. Its methodological basis is postmodernism and social constructivism, and the subject area is discourse and its components. Discourse has a thoughtcommunicative nature and refers to the type of objects that can be adequately interpreted only in the light of the non-linear paradigm according to which meaning is not contained in discourse but is constructed by communicants in the course of social interaction taking into account the social and cultural properties of the communication situation and cognitive aspects of communicants. The principle of constructivism allows us to see how the meanings of individual linguistic utterances are jointly formed by two communicants.

The practical significance of communication research in the light of the linguisticcognitive paradigm is to enable people to understand each other better when communicating, because problems of mutual understanding often arise even among people belonging to one language culture and one social group, and in intercultural communication problems of understanding even more urgent. Thus, applying the results of studying communication in practice in the light of the cognitive-communicative paradigm can make communication more effective.

\section{REFERENCES}

1. Jackendoff R. Semantics and Cognition. 6th ed. Cambridge (Mass.): The MIT Press. 1993. - 283 p.

2. Jürgen Habermas. Moralbewusstsein und kommunikatives Handeln. Suhrkamp, Frankfurt am Main, 1983.

3. Teun A. van Dijk. News Analysis. Case studies of international and national news in the press. Hillsdale, NJ: Erlbaum, 1988. 325 p. - P. 2.

4. Макаров Л.М. Основы теории дискурса. - М.: Гнозис, 2003. -280 с.

5. Langacker R.W. Discourse in cognitive grammar // Cognitive Linguistics. - 2001. - Vol. 12, R 2. - P. 143 - 188.].

6. Holland D. and Quinn N. Cultural Models in Language and Thought. London, New York et al.: Cambridge University Press, 1987.

7. Lakoff G. and Johnson M. Philosophy in the Flesh. The Embodied Mind and Its Challenge to Western Thought. N.Y.: Perseus Books, 1999. - 624 p. 